International Journal of Social Sciences and Humanities
Available online at http://sciencescholar.us/journal/index.php/ijssh
Vol. 2 No. 3, December 2018, pages: 12 20
e-ISSN: 2550-7001, p-ISSN: 2550-701X
https://doi.org/10.29332/ijssh.v2n3.183

\title{
Social Capital, Spiritual Capital, Human Capital, and Financial Capital in the Management of Child Welfare Institutions
}

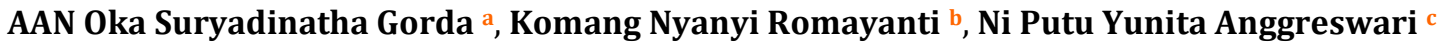

Article history: Received 10 April 2018, Accepted: 2 September 2018, Published: 8 September 2018



Keywords

Financial Capital;

Human Capital;

Organizations;

Social Capital;

Spiritual Capital;

\begin{abstract}
Child Welfare Institutions (LKSA) are social organizations or associations that carry out social welfare which is formed by the community and is a legal entity based on national standards for childcare. This standard is part of an effort to encourage the transformation of the role of the orphanage and to position the institutions as alternatives in the childcare continuum for those who cannot be cared for in the main family, extended family, relatives, or substitute families. In line with this, the LKSA must function as a service center for children and their families. This is an effort to implement care and protection for children who are outside of family care and is a form of implementation of national legislation, both Law Number 4 of 1979 concerning Child Welfare and Law Number 23 of 2002 concerning Child Protection, which governed the importance of parenting by parents and families; but this has not been fully fulfilled at the level of implementation. Data collection in this study is qualitative data and quantitative data. Data sources used are primary data sources and secondary data sources. The data collection technique used are observation method, documentation method and a structured interview with purposive systematic sampling technique. The number of informants used were 8 people. While the data analysis technique is divided into three stages, namely, data collection, data reduction, and data presentation. Verification of the validity of the results of the analysis is using the source triangulation. Basically, humans have a fairly high sense of social level. Humans/employees cannot live alone especially in managing LKSAs. Employees need other people as co-workers. Work in a team.
\end{abstract}

e-ISSN: 2550-7001, p-ISSN: 2550-701X ๑Copyright 2018. The Author. SS Journals Published by Universidad Técnica de Manabí. This is an open-access article under the CC BY-SA 4.0 license

(https://creativecommons.org/licenses/by-sa/4.0/) All rights reserved.

a Faculty of Law and Social Science, Undiknas University, Bali, Indonesia

b Master Degree, Undiknas University, Bali, Indonesia

c Faculty of Law and Social Science, Undiknas University, Bali, Indonesia 


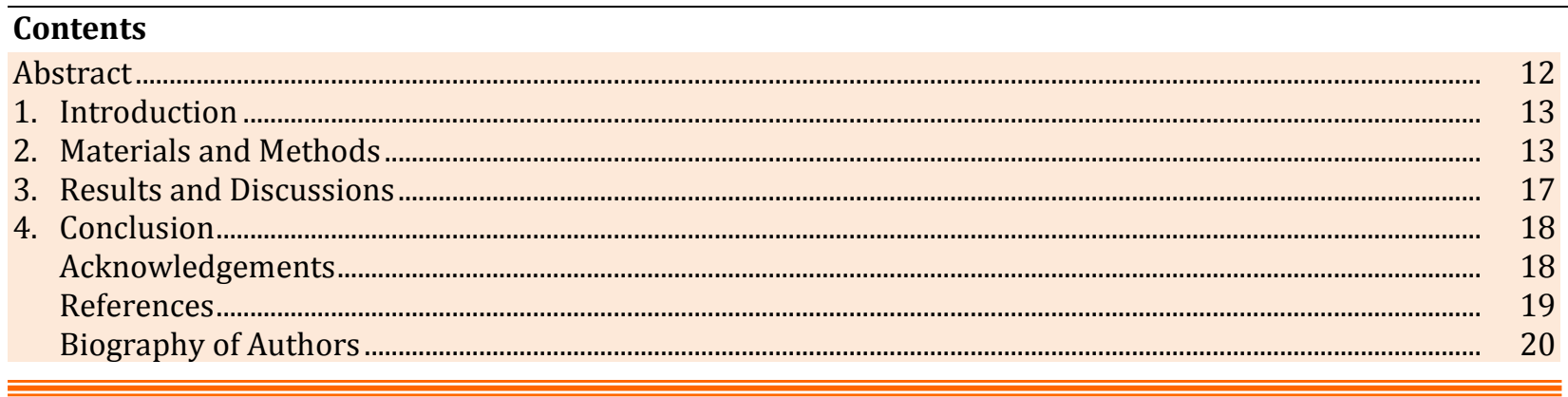

\section{Introduction}

For the continuity and harmony of children's services and management in these institutions, there is a need for capital to support a person to be able to join the institution. Due to the life as a human cannot live without the help of others. Therefore we need mutual respect for each other. One of them is social capital.

The essence of social capital lies in the level of commitment of its citizens which is reflected through its involvement in social relations, especially membership in organizations and groups Sila Pertikasari, Mardiyono, Solih Mu'adi (2016). Bourdieu and Wacquant, (1992: 119) define that social capital includes resources both actual and virtual (potential), networks and relations that respect or give attention. Putnam (1993: 35) says that social capital is inherent in social relations. Those who work in children's social institutions are people who have a sense of calling. They feel asked to share their wealth in meeting the needs of society, humanity and a wider life. They are grateful for any contribution they can make to themselves or the wealth of the world and the welfare of the people of the world. They do not receive anything to give (Zohar \& Marshall, 2004). With the fulfillment of spiritual capital, a person will be called to serve with love and supported by the existence of deep goals. On the basis of self-confidence, the capital that is in a person can do everything related to the management of the LKSA. The capital in question is human capital. Human Capital is an asset that is visible (tangible assets), namely, knowledge, expertise, ability, and skills that make people (employees) as capital or assets of a company (Chr Jimmy L. Gaol, 2014: 696). A person can be motivated and ready to do something if there are things that are seen clearly and can be measured. Because something is real, someone can see and they can get it easily and surely. One of the measuring tools for someone doing the work they do. The size of the work is assessed based on the salary they receive each month. This is what sometimes makes someone interested in joining a particular company. Because the results they receive are appropriate or not can be ascertained by them. It can be called as the financial capital or tangible assets. Financial capital is defined as the accumulative ownership of goods and services through the financial system in the form of salaries, income, subsidies, and deposits (Mora \& Perez: 2018). Financial capital is one of the drivers in the management of LKSAs. Financial capital is financial support owned by a community that can be used to finance the development process held in the community. One indicator that describes people's financial capital is to see the number of people who are below the poverty line (Nuryani, et al.: 2018).

\section{Materials and Methods}

This research was conducted at the Social Service of Buleleng Regency. This research is a qualitative descriptive study using a phenomenon approach and researchers use this type of qualitative research because qualitative types, as research procedures, produce descriptive data in the form of written and verbal words from people and actors observed to be directed to the background and individuals holistically. The type of data used by researchers in conducting research is qualitative data and quantitative data. According to Sugiyono (2015), the types of data are divided into 2, namely qualitative and quantitative. This study uses data types in the form of qualitative and quantitative. Qualitative data are data in the form of words, schemes, and images. This research uses qualitative descriptive in the form of personal documents, field notes, respondent's words and actions, documents and others.

Gorda, A. O. S., Romayanti, K. N., \& Anggreswari, N. P. Y. (2018). Social capital, spiritual capital, human capital, and financial capital in the management of child welfare institutions. International Journal of Social Sciences and Humanities, 2(3), 12-20. https://doi.org/10.29332/ijssh.v2n3.183 
Quantitative data are data in the form of numbers, such as data on conditions and number of LKSAs in Buleleng regency from the Ministry of Social Affairs and the LKSA Annual Work Report. The informant selection technique used purposive sampling technique with a total of 8 (eight) informants. Data was collected using interview instruments. The data analysis technique used is in accordance with Miles and Huberman techniques in Sugiyono (2017) which says that there are three methods in qualitative data analysis, namely: Data reduction, Data display, and Conclusion drawing/verification. Verification of the validity of the results of the analysis is using data source triangulation which means analyzing the level of accuracy and accuracy of data from 2 (two) different data sources, which are related to the object of research, namely from taxpayers and tax officers (Dewi, et al.: 2017).

\section{Theories}

\section{a) Motivation Theory}

Pajak Sutrisno (2014 p. 186) in Roymond Tan and Zeplin Jiwa Husada Tarigan (2017) explains that motivation is a factor that encourages a person to do a certain activity, therefore motivation is often interpreted as a driving factor of someone's behavior.

\section{b) Social Capital}

According to Pierre Bourdieu and Wacquant, (1992: 119) 'Social Capital is the sum of resources, actual or virtual, that accrue to an individual or group by virtue of possessing a durable network of more or less institutionalized relationships of mutual acquaintance and recognition.' That is, social capital includes a number of actual or virtual resources caused by individuals or groups with strong network relationships by getting to know each other and other acquaintances. According to James Coleman of Sunyoto Usman, (2018; $24)$ "social capital is a representation of resources in which relationships are mutual - reciprocal relationships, social networks that institutionalize trust.

Putnam gives a concise definition of social capital: "by 'Social capital' I mean features of social life networks, norms, and trust - that enable participants to act together more effectively to pursue shared objectives" (Putnam 1996: 56 in Baron, Field and Schuller, 2000). These three elements - networks, norms, and trust - are triangles that dominate Putnam's conceptual discussions which emphasize differences in social capital with other capital Social capital is part of the social life of the network, norms, and beliefs (Field, 2010: 5). Putnam describes the differences as follows:

"Whereas physical capital refers to physical objects and human capital refers to the properties of individuals, social capital refers to connections among individuals - social networks and the norms of reciprocity and trustworthiness that arise from them. In that social capital, the sense is closely related to what some have called "civic virtue." The difference is that 'social capital' calls attention to the fact that civic virtue is most powerful when embedded in the sense of networking of reciprocal social relations. A society of many virtues but isolated individuals is not necessarily rich in social capital "(Putnam, 2000: 19 in Suharjo, 2014).

\section{c) Spiritual Capital}

In the management of social institutions children cannot be separated from the spiritual capital. The institutions protect children who have high hopes for the institution and caregivers who will guide them. Likewise, to manage the institution, they live together in everyday life, feel each other and having the same goals. According to Zohar \& Marshall, (2004) in Nurul Fuada, Hamid Habbe, and Nirwana (2015) found that Spiritual Capital as wealth helps to maintain future humanity and wealth that nourishes and maintains human spirit. Another opinion described by Eko Jalu Santoso (2004: 261) about spiritual capital is that: "The measure of prosperity is not determined by how much it earns, but by how many people it invites to share that prosperity. Believing positive energy is not lost from life, but will flow back into us. We do not need to worry about being poor, there is no need to worry about the future that is not sure to come back. This is a necessity or a true natural law."

\section{d) Human Capital}

According to chr. Jimmy L. Gaol (2014: 696) human capital is knowledge, expertise, ability, and skills that make humans (employees) as capital or assets of a company. Human capital is the knowledge, skills, 
experience, and other relevant workforce attributes that help an organization's workplace and drives productivity, performance, and the achievement of strategic goals. The point is that human capital is the amount of knowledge, expertise, experience, and labor that are relevant to other attributes that exist in an organization and which drive productivity, performance as well as manage to achieve strategic goals.

\section{Financial Capital}

The most common financial capital refers to assets needed by a company to provide goods or services or by someone for its own needs, which is measured in terms of the value of money. Money arising from debt and equity problems is usually referred to as capital. Financial capital is defined as the accumulative ownership of goods and services through the financial system in the form of salaries, income, subsidies, and deposits. "

1) Salaries are generally payments for the delivery of services performed by employees who have managerial positions, while wages are generally payments for service conducted by the executing employees (laborers). Generally, salaries are paid regular monthly, while wages are paid based on working days, working hours or the number of product units produced, Mulyadi (2016: 309). A salary is a form of payment or a right granted by a company or agency to employees. Based on the above opinion, it can be concluded that salary is a remuneration given to employees who have strong work ties on a regular basis based on the applicable provisions in the company and its permanent nature Mardi (2011: 107).

2) Revenue / Revenue. Revenues are all receipts in the form of money or in the form of goods originating from other parties or industrial products that are valued on the basis of a sum of money from the assets that were in effect at that time. Income is a source of revenues for someone to fulfill their daily needs and is very important for the survival and livelihood of a person directly or not (Suroto, 2000).

3) Subsidies, Subsidies are assistance provided with the aim of reducing the burden. According to Erwan in his writing (Erwan, 2010) which further explained about subsidies that subsidies are a gift (contribution) in the form of money or financial given by the government or a public body. The government contribution can be in the form of Direct transfer of funds such as grants, loans, and investments, transfer of funds or direct guarantees of debt; loss of government revenue or fiscal exemptions (such as tax relief); provision of goods or services outside of public infrastructure or purchase of goods. The government makes payments to the funding mechanism or authorizes a private entity to carry out government duties in terms of providing funds. Besides this, all forms of income and price support are also subsidies if the assistance raises an advantage (Afdhal Ilahi, 2018).

Gorda, A. O. S., Romayanti, K. N., \& Anggreswari, N. P. Y. (2018). Social capital, spiritual capital, human capital, and financial capital in the management of child welfare institutions. International Journal of Social Sciences and Humanities, 2(3), 12-20. https://doi.org/10.29332/ijssh.v2n3.183 
Conceptual Framework

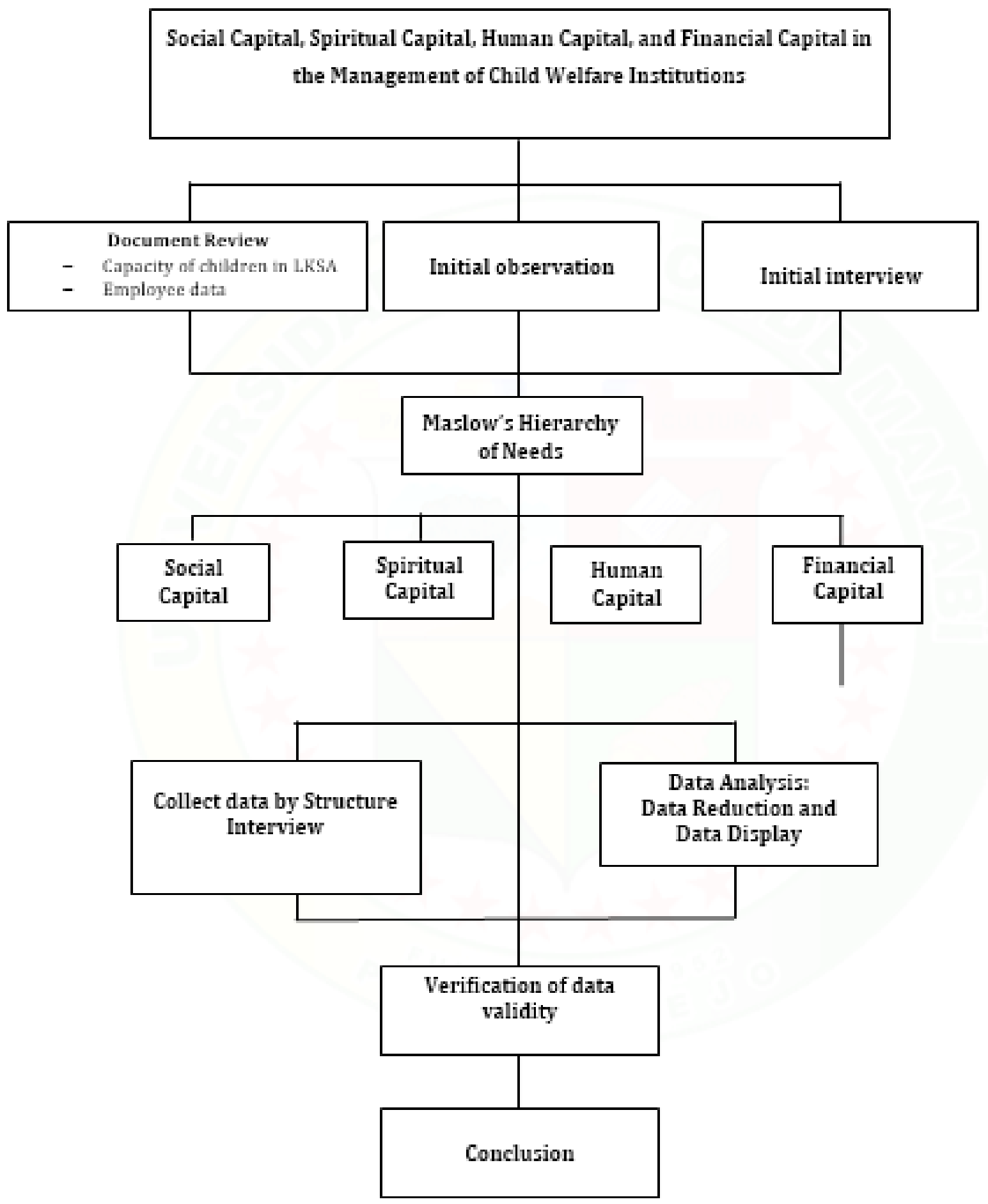




\section{Results and Discussions}

\subsection{Social Capital}

LKSA Saiwa Dharma empowers students as co-workers while contributing to the management of LKSAs both in the administration and in assisting the younger siblings at the LKSA. Sila Pertikasari, Mardiyono, Solih Mu'adi (2016) said that the core of social capital lies in the level of commitment of its citizens which is reflected through its involvement in social relations, especially membership in organizations and groups.

Co-workers are an asset for informants, informants can ask colleagues about a lot of things about LKSA, in addition to google that can help. The informant also strongly believes in the journey while serving at the LKSA, because of the cooperation and mutual support. As expressed in coordinating the LKSA's heads in Buleleng Regency. James Coleman in Sunyoto Usman, (2018; 24) says that "social capital is a representation of resources in which relationships are mutual reciprocal relationships, social networks that institutionalize trust.

Based on the results of interviews with informants it was said that to complete a job is not easy if it is done alone so that in work, it will always need partners to be able to work together and help children. Moreover, for assignments outside the city, it takes people who can be trusted to be able to delegate tasks. A leader should be able to maintain a good and harmonious relationship within the organization and be able to create a conducive work climate so that LKSA services can be improved.

James Coleman in Sunyoto Usman, (2018; 24) stated that "social capital is a representation of resources in which relationships are mutually beneficial -reciprocal relationships, social networks that institutionalize trust. The joy of LKSA is the high principle of kinship, the feeling of comfort and love for the LKSA grows with time. Certainly, a friend who can be invited to work is quite a lot because, without cooperation, service will not work as it should. The strength of the teamwork is huge because otherwise the service will not be maximized. Caring for and educating children to be "someone" is a success that has been achieved with teamwork. Francis Fukuyama (1995: 10), stated that social capital is the ability of people to work together for general goals in groups or organizations.

\subsection{Spiritual Capital}

The Head of the LKSA is motivated to manage the LKSA because there is a motivating thing within himself, namely "Life must mean something"; Life becomes meaningful when it can help others and share. As stated in the Hindu teachings, namely, Moksartham Jagadhita ya ca iti Dharma", which means that religion (dharma) aims to achieve spiritual happiness and the welfare of physical life or happiness both physically and physically (Moksa). There is nothing else to pursue other than moksha. There are also employees who manage LKSA on the basis of reciprocity because there were already assisted and raised in LKSA as well as their sense of happiness when interacting with children of LKSA. Felt asked to share in meeting the needs of society, humanity, and broader life; Danah Saturn and Ian Marshall (2004). A sense of gratitude for the contributions that these employees can give to children or the wealth of the world and the welfare of the people of the world

All work in the LKSA is carried out just like carrying out Yadnya, which is a sincere work with no strings attached. Providing assistance to those who are economically disadvantaged and provide services are for LKSA children. The work done by LKSA organizational members is based on the belief in the law of karma, namely "do good and good things will come to you." The Christian Bible contained in (Galatians 6: 2) states that: Bear your burdens while helping others! Thus you fulfill the law of Christ. Serving children also serve God. Educate, bless, and make LKSA children become good and faithful children. Directing children into the realm of divine power and making humans aware of their mandate as khalifatullah fil ardh (God's representative on earth) and Abdullah (servant of Allah) Triyuwono, (2012).

\subsection{Human Capital}

Didi Mohatita acknowledges that he has a social education background. Doing things that are social has become a habit. That is what makes happy informants. The informant did not say how much education and

Gorda, A. O. S., Romayanti, K. N., \& Anggreswari, N. P. Y. (2018). Social capital, spiritual capital, human capital, and financial capital in the management of child welfare institutions. International Journal of Social Sciences and Humanities, 2(3), 12-20. https://doi.org/10.29332/ijssh.v2n3.183 
other factors motivate the informant to do this, everything went as it is. Mr. Franky and Mr. Kadek Pihilipus are employees (informants) who have a theological education background. The informant managed the LKSA based on religious knowledge. Knowledge, expertise, ability, and skills make humans (employees) as capital or assets of a company or institution, chr. Jimmy L. Gaol (2014).

The most interesting part of LKSA Saiwa Darma is when everything is done together. All who are in the LKSA are brothers and sisters, so doing service and working in the LKSA is the responsibility for him. Holding administration and other duties were learned from the older siblings. The informant confirmed that the informants were indeed alumni from the Economics school and knew about the management of the institution. Employees who work as kitchen staff and caregivers only learn by self-taught while learning in the process. Many LKSA employees only have a high school education background.

\subsection{Financial Capital}

Salary is a benchmark used by the institution as a measure of the hard work of LKSA employees. Salary is a remuneration that is given to employees who have strong working ties on a regular basis based on the applicable provisions in the company and its permanent nature Mardi (2011: 107). In addition, employees can enjoy the facilities in the LKSA, as well as the primary needs of employees, are fulfilled such as eating with children, adequate room facilities, personal needs such as toiletries and routine health checks from the health team.

\section{Conclusion}

Basically, humans have a high social sense, so that humans cannot live alone, as well as in managing LKSAs where employees need other people as co-workers. Working in a team is able to create family relationships between staff, children, and donors. Employees are also given motivation so that religious values are embedded in their hearts. These values are Yadnya or service to God by doing well for the environment.

Judging from human capital, employees only manage LKSAs with existing channels. Self-taught learning from trusted sources, the educational background of LKSA employees does not support the management of LKSAs. The person who manages the LKSA does not have a higher education background and there is no expertise in the field of LKSA management. As employees who are directly in contact with children should have a background in social education namely social welfare. Whereas, it's managed the LKSA, who directly control and manage the LKSA should have an educational background in management and administration. Financially, LKSAs have a role in making employees feel safe. Primary needs are met by preparing a clean place to live, healthy food also by ensuring their health by providing regular treatment from the health team and BPJS subsidies.

\section{Acknowledgments}

The authors would like to thank the editor of the International Journal of Social Sciences and Humanities for their support, valuable time, and advice. 


\section{References}

Baron, S., Field, J., \& Schuller, T. (Eds.). (2000). Social capital: Critical perspectives. OUP Oxford.

Bourdieu, P. (1992). Thinking about limits. Theory, Culture \& Society, 9(1), 37-49.

Bourdieu, P., \& Wacquant, L. (1992). An Invitation to Reflexive Sociology. Chicago und London: The University of Chicago Press.

Coleman, J. S. (1988). Social capital in the creation of human capital. American journal of sociology, 94, S95S120.

Danah, Z., \& Marshall, I. (2004). Spiritual Capital: Wealth We can Live by.

Dewi, I. G. A. A. O., \& Dewi, I. G. A. A. P. (2017). Corporate Social Responsibility, Green Banking, and Going Concern on Banking Company in Indonesia Stock Exchange. International Journal of Social Sciences and Humanities (IJSSH), 1(3), 118-134.

Field, F. (2010). The Foundation Years: preventing poor children becoming poor adults, The report of the Independent Review on Poverty and Life Chances. The Stationery Office.

Fukuyama, M. F. (2000). Social capital and civil society. International Monetary Fund.

Gaol, C. J. L. (2014). A to Z Human Capital. Gramedia Widiasarana Indonesia.

Gaol, J. L., \& Jimmy, L. (2014). A to Z Human Capital Manajemen Sumber Daya Manusia. PT. Gramedia Widiasarana Indonesia. Jakarta.

Ilahi, Afdhal. Penerapan model pembelajaran berbasis portofolio pada mata pelajaran agama islam di madrasah tsanawiyah hasanah pekanbaru. Diss. Universitas Islam Negeri Sultan Syarif Kasim Riau, 2014.

Luthfi, M. (2017). Analisis Pengaruh Spiritual Capital Terhadap Kinerja Karyawan Serta Dampaknya Pada Keunggulan Bersaing" (Bachelor's thesis, Jakarta: Fakultas Ekonomi Dan Bisnis UIN Syarif Hidayatullah.).

Mardi, Z., Ashtiani, S. N. M., \& Mikaili, M. (2011). EEG-based drowsiness detection for safe driving using chaotic features and statistical tests. Journal of medical signals and sensors, 1(2), 130.

Miles, M. B., \& Huberman, A. M. (1994). Qualitative data analysis: Grounded theory procedures and techniques.

Mora, M. M., Espinosa, M. R., \& Perez, A. V. (2018). Social role of economic and financial management in Ecuadorian universities. International Research Journal of Management, IT and Social Sciences, 5(4), 61-70.

Mulyadi, S., Rahardjo, W., \& Basuki, A. H. (2016). The role of parent-child relationship, self-esteem, academic self-efficacy to academic stress. Procedia-Social and Behavioral Sciences, 217, 603-608.

Nuryani, N. N. J., Satrawan, D. P. R., Gorda, A. A. N. O. S., \& Martini, L. K. B. (2018). Influence of human capital, social capital, economic capital towards financial performance \& corporate social responsibility. International Journal of Social Sciences and Humanities (IJSSH), 2(2), 65-76.

Pertikasari, S., Mardiyono, M., \& Mu'adi, S. (2016). Kajian Tentang Modal Sosial Sebagai Pendorong Peran Serta Lembaga Lokal Dalam Upaya Penanggulangan Kemiskinan (Studi Kasus di Desa Grinting, Kecamatan Tulangan, Kabupaten Sidoarjo). WACANA, Jurnal Sosial dan Humaniora, 19(4).

Putnam, R. D. (2001). Bowling alone: The collapse and revival of American community. Simon and Schuster.

Santoso, E. J. (2004). The Art of life revolution. Elex Media Komputindo.

Sudarman, S., \& Suroto, P. (2000). K., and Aspiyo, S., 2000: Geothermal development progress in Indonesia: country update 1995-2000. In Proceedings of the World Geothermal Congress 2000, Kyushu-Tohoku, Japan (pp. 441-454).

Sugiyono, A., \& Anindhita, B. (2014). Outlook Energi Indonesia 2014. Pusat Teknologi Pengembangan Sumberdaya Energi. Badan Pengkajian dan Penerapan Teknologi.

Sugiyono, D. (2008). Metode Penelitian Bisnis. Bandung: Pusat Bahasa Depdiknas.

Suharjo, R., Sawada, H., \& Takikawa, Y. (2014). Phylogenetic study of Japanese Dickeya spp. and development of new rapid identification methods using PCR-RFLP. Journal of general plant pathology, 80(3), $237-254$.

Sutrisno, H. (2000). Metodologi research. Yogyakarta, Penerbit Psikologi Universitas.

Tan, R. (2017). Pengaruh Kompensasi dan Kepuasan Kerja terhadap Organizational Citizenship Behavior (Ocb) melalui Motivasi Kerja sebagai Variabel Intervening pada 3h Motosport. Agora, 5(1).

Tarigan, Z. J. H. (2005). Integrasi Teknologi RFID dengan Teknologi ERP untuk Otomatisasi Data (Studi Kasus pada Gudang Barang Jadi Perusahaan Furniture). Jurnal teknik industri, 6(2), 134-141.

Triyuwono, I. (2015). So, What is Sharia Accounting?. Imanensi, 1(1), 42-50.

Usman, S. (2004). Sosiologi: Sejarah, Teori dan Metodologi. Yogyakarta: CIReD.

Usman, Sunyoto. (2018). Social Capital. Yogyakarta. Student Library (Members of IKAPI).

Zohar, D., \& Marshall, I. (2004). Spiritual capital: Wealth we can live by. Berrett-Koehler Publishers.

Gorda, A. O. S., Romayanti, K. N., \& Anggreswari, N. P. Y. (2018). Social capital, spiritual capital, human capital, and financial capital in the management of child welfare institutions. International Journal of Social Sciences and Humanities, 2(3), 12-20. https://doi.org/10.29332/ijssh.v2n3.183 


\section{Biography of Authors}

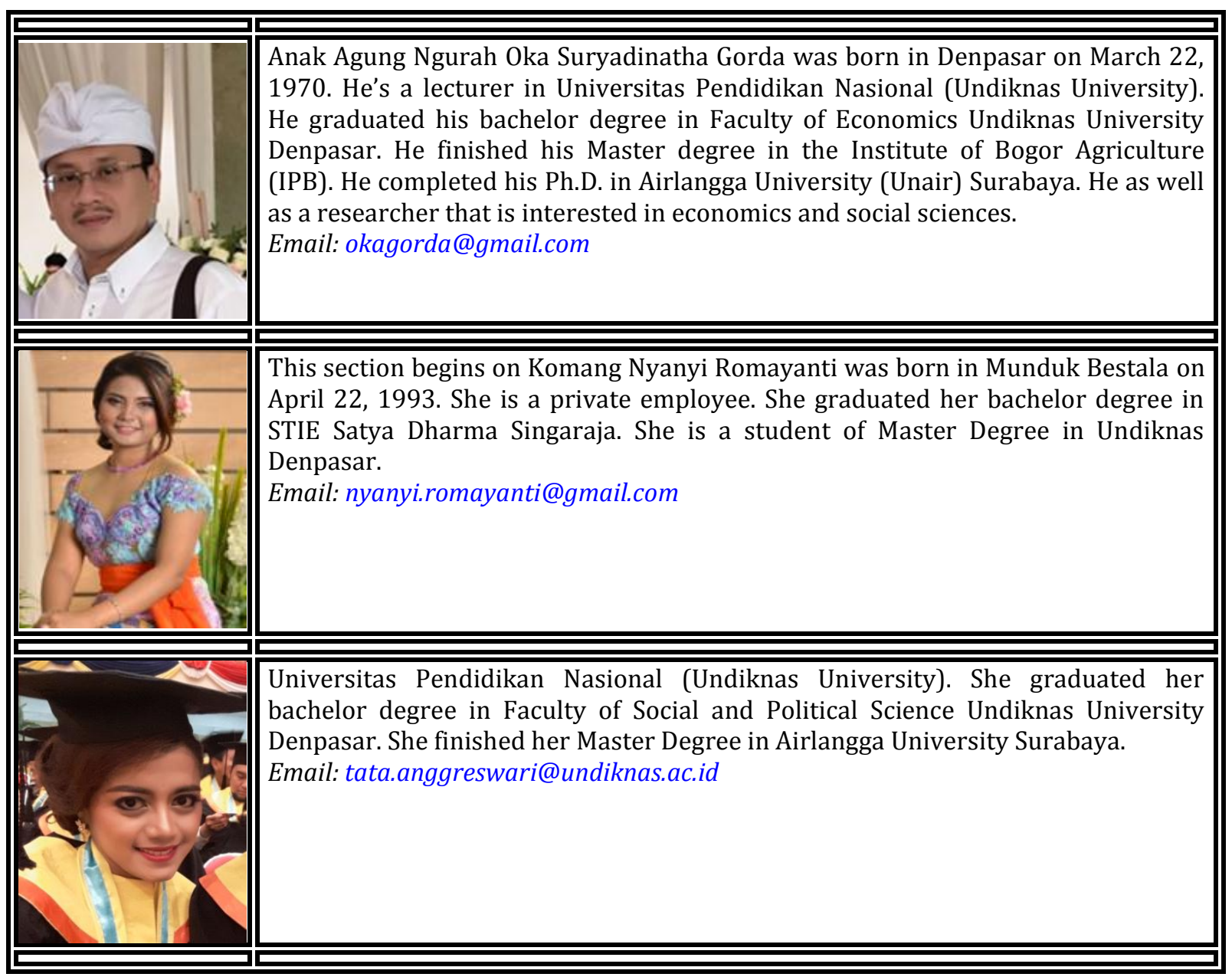

